\title{
TRAINING ON PUBLIC SPEAKING OF DAHUNI FOUNDATION FOR HIGH SCHOOL STUDENTS IN BOYOLALI - CENTRAL JAVA
}

\author{
Fizzy Andriani \\ Prof. Dr. Moestopo (Beragama) University \\ fifi_fizzy@yahoo.com
}

\begin{abstract}
The art of public speaking is a skill that should be mastered by high school students. For this reason, public speaking training is important for high school students in Boyolali, because there are still many of them who are afraid and anxious when speaking in front of a large audience. This activity aims to improve the quality of human resources with the target of high school students in Boyolali in an effort to improve skills and confidence when speaking in front of the public.
\end{abstract}

Keywords: Public speaking training, improving quality of human resources, high school students

\section{INTRODUCTION}

Industrial development and global competition require adequate quality of human resources (HR), to prepare and assist the implementation of education in Indonesia. But the good quality of human resources is not enough if it is not equipped with the ability to communicate well. The ability to communicate well is needed, including the ability of public speaking or the ability to speak in front of the public.

There are at least two main reasons, according to Prochnow (1955: 34) which underlie why someone studies public speaking seriously, "There are two main reasons for systematic study of public speaking. The first is necessity. The need to speak clearly and forcefully is invaluable in achieving success in your business or professional work. The second reason is enjoyment."

There are fundamental differences that distinguish between public speaking and conversation. This difference is clearly expressed by Lucas (2004: 9), "(1) Public speaking is more highly structured. It usually imposes strict time limitations on the speaker. In most cases, the situation does not allow the listeners to interrupt with questions or commentary. The speaker must accomplish her or his purpose in the speech itself. In preparing the speech, the speaker must anticipate questions that might arise in the minds of listeners and answer them. Consequently, public speaking demands much more detailed planning and preparation than ordinary conversation. (2) Public speaking requires more formal language. Slang, jargon, and bad grammar have little place in public speech. (3) Public speaking requires a different method of delivery."

Public speaking has now become one of the needs in various companies, both for external and internal communication. School students, from elementary to high level, are considered to be in the early need of public speaking training. This activity is carried out to motivate and provide opportunities for students in Boyolali to improve themselves and improve competence towards global competition, especially in enhancing knowledge in Indonesian language. In addition, this activity aims to socialize the scholarship program held by the Dahuni Foundation for students who excel and do not have the financial ability to continue their studies to a more advanced level.

Poverty is one of the inhibiting factors for the improvement of education in addition to the lack of motivation of students to complete their education becoming a problem that needs to be solved together. The gap in getting education is the objective of the activities carried out by the teaching team from the Faculty of Communication Studies, University of Prof. Dr. Moestopo (Beragama) with Dahuni Foundation, held from 24 to 29 April 2017 in Boyolasi. The activities include: English language training and TOEFL test, Multicultural booth, Scientific Writing Workshop delivered by Dr. Eni Kardi, Public Writing Workshop by Fizzy Andriani, MSi, and Creative Writing Workshop by Dwi Ajeng Widarini, MI. Kom 
Collaboration to solve the problem of education is something that can be done for improving education in Indonesia. This collaboration was carried out by Dahuni Foundation, Fikom UPDM (B), and several volunteers from several countries, such as the Netherlands, the United States, Korea, Poland, Ukraine, Slovakia and India. One of the activities carried out in this program is Public Speaking Training for high school students in Boyolali. This training will make them have the courage and the ability to speak in front of the public, starting from their own classroom environment.

For the short term, public speaking training will at least make students able to deliver presentations in front of their friends and teachers, and be able to speak in the school environment in front of the teachers and parents. For the medium term, when they continue their education in colleges, they will have the ability to defend their thesis in front of a thesis trial. For the long term, when the time comes for them to find work, the ability of public speaking is very useful in dealing with job interviews. Of course there are many other benefits of this public speaking ability for the future of students.

\section{METHOD}

Training activities were carried out by asking the students to go forward and speak in front of the class with their own chosen materials. They may make themselves as any profession, be it MC, Stand Up Comedian, Campaign, Spokesperson and others. There were no special assessments, because this training was intended to increase students' confidence first. Considering that most of them were still nervous and afraid to speak in public, the theme was free according to the wishes of the students, and the training was made a little interactive in order to be interesting. Meanwhile, in delivering a speech, Jalaludin Rakhmat said there were several principles, namely: face-to-face communication, which is two-way. Although the speaker dominates the conversation more, he/she must "listen" to the messages conveyed by the listeners (both in the form of words and non-words); Characteristics of vocals, where speeches, such as theater, are very dependent on acting. One element of acting is vocal. In this book there are a number of things that must be considered in vocals: clarity, diversity, and rhythm; and visual processing, where body movements during speech will make the audience move. They will feel what you feel. For communicators, physical movement can channel added energy into his body. Thus, he/she reduces communicator's anxiety and increases self-confidence (Rachmat: 2008).

This training uses several common techniques in public speaking training, as quoted from http://indosdm.com/public-speaking-pedoman-berbicara-di-depan-publik, including: the speaker must appear in front or in a position that can be seen by the audience. The goal is that what is conveyed by the speaker can be the attention of the audience; Convey ideas with the volume heard by all audiences, choose the right words, clear pronunciation, and appropriate intonation; the presence of eye contact, where the direct gaze to the audience can have an impact that the audience feels invited to talk to. This will make the audience pay attention to the speech; use natural expressions and body languages by doing a little movement for the audience, and able to speak and close the speech properly.

\section{RESULT AND DISCUSSION}

The implementation of public speaking training for high school students in Boyolali used a form of basic training, which includes training the courage of students to stand in front of the class to be seen by the entire audience, train the courage of students to speak in a voice that can be heard clearly by the whole audience, training the courage of the students to talk while looking at the audience in turn, training the students to be able to control their expression and body language when conducting public speaking, and finally, training students to be able to speak well and correctly and close the speech interestingly. 


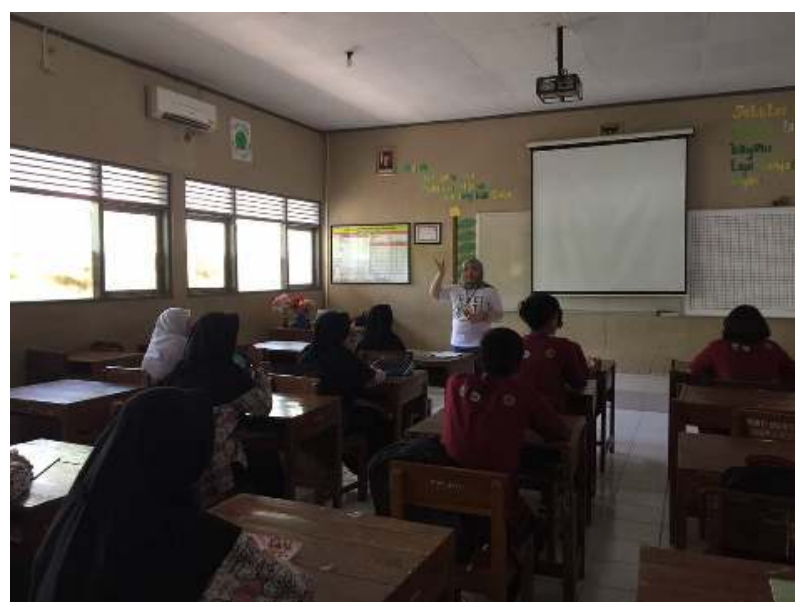

Figure 1. Public Speaking Workshop on the first day

In the stage of training the courage of the students to stand in front of the class so that they are seen by the entire audience at first was rather difficult, because they still felt ashamed of making mistakes in front of their friends. So that at this stage the trainer asked anyone who dares to appear first, and allows them to talk about what they like and understand. The trainer also did not provide time limits for students.

After the first student came forward and told the story and then experienced obstacles such as not knowing what to say anymore, the trainer was trying to break the ice by giving a few simple questions related to the materials that the students brought, and it was believed that the questions would be able to be answered by students and make students able to tell more. Involving other students to ask questions could also be done. If the atmosphere become more pleasant, students who appeared in front would begin to feel relaxed and the story would flow more smoothly. The success of the students who appeared first would give an example to their friends, so they could be more courageous to come forward.

The obstacle they felt was the fear of being wrong and not confident. Most students could finally be asked to move forward, although some of them needed a little persuasion. After they finished doing public speaking, they said they were very scared at the beginning, but after speaking in front of them they became relaxed. For the stage of training the courage of students to speak in a voice that can be heard clearly by the whole audience, it was also almost the same as the previous stage. Quite a lot of students still lacked the courage to tell stories loudly and clearly heard. And many of them also told stories with a halt; even some were silent when they were doing public speaking.

When they just tried to appear in front, a sense of insecurity made them speak in a low voice. Although quite a number of them had dared to speak in a clear voice. But because the room is quite small and the number of students in the class is only a little, this low voice problem could be overcome. They revealed that their nervousness and fear made them forget about the material they had previously prepared. They said that the material they had prepared was material they understood, but when they were in front, they felt like they didn't know what else they had to say because everything was lost in their minds.

To overcome this, the atmosphere could be made more pleasuring by asking light questions or joking a little, then asking them to add a little volume. Questions that could be asked were usually around themselves, such as what their hobbies were, or activities they liked or often did. These questions could make them more relaxed and then be able to continue their story more smoothly.

However, the problem of voice and halting sentences occurred more at the beginning of the session every day. The longer, they saw more and more friends, who appeared, the more they felt relaxed. Not only that, the class atmosphere even felt more relaxed. This could be seen from how the friends of the students who appeared had begun to try to help their friends to be more relaxed, both by giving a positive response showing they were interested in the materials, also with a little joke. This seemed very capable of raising the confidence of students who were doing public speaking.

While at the stage of training the students' courage to talk while looking at the audience, very few students were able to do it. Most students did not have the courage to talk while looking at the audience. 
They tended to choose one point that became their focus of view. The focus of their view could be on the back wall of the classroom, outside the room, the bottom or top of the classroom, the classroom or even moving around.

They, for the most part, tried to avoid audience gazes. But this only happened in the beginning when they started to appear for public speaking. After a few minutes, when they began to find their comfort points, they gradually began to dare to look at the audience, although sometimes they had to be reminded again. However, there were still quite a number of those who were reminded to start looking at their audience, they suddenly forgot their material, their speech began to stutter, and finally they again avoided looking at the audience.

This condition describes how their confidence had not yet been mastered. Public speaking was still a scary thing for them. But as a beginner, this did not matter much. But it was important to be a concern, to continue activating students in public speaking. So that they would get used to public speaking, and it was expected that things like this would be minimized.

For the stage of exercising their expression and body language when doing public speaking, it showed the same thing with eye contact. They were still very difficult to eliminate the expression of panic and fear on their faces. In speaking they still saw expressions of memorization, including expressions of thought. The expression was clearly illustrated, so that the audience could feel it.

A similar thing was also seen in their body language. They did a lot of repetitive movements, such as left-to-right movements, finger or hair playing movements, holding a skirt and pants at presentation, looking down, and also putting their hands behind. Everything they did also illustrated the discomfort that arose in them. These movements were like their efforts to calm and minimize the discomfort they felt.

All forms of discomfort occurred to all students, especially at the beginning of their appearance. Towards the end, some of them began to find comfort so the expression and body language as above began to decrease. But it was still very minimal.

And finally, the stage of training students to be able to speak well and correctly and close the speech interestingly. At this stage not many students were able to do it especially if it was associated with the use of formal language. Almost all students continued to use informal language, but were still good, proper and polite. And considering this is training for beginners, it was still be acceptable, with the expectation that later they would develop in the implementation for the better.

\section{CONCLUSION}

Activities in an effort to improve education in Indonesia must be carried out in order to improve education in Indonesia evenly and sustainably. Especially in regions that still have potentials for development in the human resource development sector. This activity can be a real collaboration in improving education and reducing the education gap. It is expected that this activity will continue, given that training like this is very much needed while students still rarely get it.

The implementation of public speaking training for high school students in Boyolali is still just a basic form of training, which includes training the courage of students to appear in front of the class to be seen by the entire audience, training the courage of students to speak in a voice that can be heard clearly by the entire audience, training the courage of the students to speak while looking at the audience in turn, training the students to be able to control their expression and body language when conducting public speaking, and finally, training the students to be able to speak well and correctly and close the speech interestingly.

Yet, in its implementation there were many adjustments, considering that students were still beginners in public speaking. So the main concern in this training is how to make them courageous to try every stage of the training. The problem faced by students is that they still feel nervous and not confident to do public speaking. Fear of being wrong, embarrassed to be laughed at, not knowing what to talk about is the feeling that the majority of students experience in this training. But considering they are new beginners, this is acceptable. The fear and lack of confidence they feel can be overcome if the trainer is not pressuring them. 


\section{REFERENCES}

Firdanianty, Djuara P. Lubis, Herien Puspitawati, Djoko Susanto. (2016). Pola Komunikasi Remaja dan Pengaruhnya terhadap Kecerdasan Emosional Siswa SMA di Kota Bogor. Jurnal Komunikasi Ikatan Sarjana Komunikasi Indonesia. Vol 1(1):37-47. http://www.jurnaliski.or.id/index.php/jkiski/article/view/34/22

Lucas, Stephen E. (2004). The Art of public Speaking. Eight Edition. New York: McGraw-Hill.

Pramono, Firdanianti, Djuara P. Lubis, Herien Puspitawati, and Djoko Susanto. (2017). Communication Pattern and Family Typology of High School Adolescents in Bogor - West Java. Jurnal Komunikasi Ikatan Sarjana Komunikasi Indonesia. Vol 2(1): 20-26. http://www.jurnaliski.or.id/index.php/jkiski/article/view/85/pdf

Prochnow, Herbert V. (1987), Penuntun Menuju Sukses dalam Berpidato, Bandung: CV Pionir

Rakhmat, Jalaludin. (2008). Retorika Modern: Pendekatan Praktis. Bandung: PT Remaja Rosdakarya

Public Speaking. (2008). Pedoman Berbicara di Depan Publik. Retrieved from: http://indosdm.com/public-speaking-pedoman-berbicara-di-depan-publik. 